\title{
Pengaruh Lama Pemeraman Terhadap Karakteristik Marshall Campuran Aspal Beton dengan Asbuton dan Bio Aditif Gondorukem
}

\author{
Hidayatul Amri ${ }^{1, *}$, I Dewa Made Alit Karyawan ${ }^{1}$, Ervina Ahyudanari ${ }^{2}$ \\ Prodi Magister Teknik Sipil, Universitas Mataram, Mataram ${ }^{1}$, Departemen Teknik Sipil, Institut Teknologi Sepuluh November, Surabaya ${ }^{2}$ \\ Koresponden*,Email: hidayatamri1088@gmail.com
}

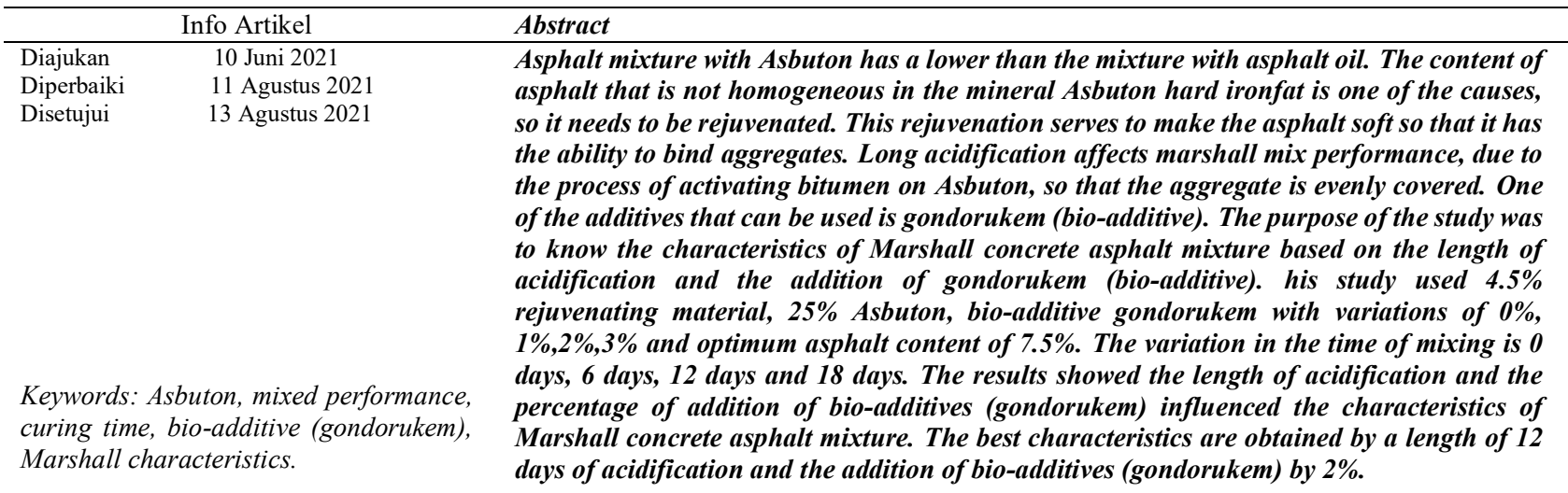

\begin{abstract}
Abstrak
Campuran aspal dengan Asbuton mempunyai yang lebih rendah dari pada campuran dengan aspal minyak. Kandungan aspal yang tidak homogen pada mineral Asbuton besifat keras merupakan salah satu penyebab, sehingga perlu diremajakan. Peremajaan ini berfungsi untuk membuat aspal menjadi lunak sehingga mempunyai kemampuan untuk mengikat agregat. Lama pemeraman berpengaruh terhadap kinerja Marshall campuran, karena terjadi proses pengaktifkan bitumen pada Asbuton, sehingga agregat terselimuti secara merata. Salah satu aditif yang dapat digunakan adalah gondorukem (bio-aditif). Tujuan penelitian mengetahui karakteristik Marshall campuran aspal beton berdasarkan lama pemeraman dan penambahan gondorukem (bio-aditif). Penelitian ini menggunakan $4.5 \%$ bahan peremaja, 25\% Asbuton, bio-aditif gondorukem dengan variasi $0 \%, 1 \%, 2 \%, 3 \%$ serta kadar aspal optimum $7.5 \%$. Variasi waktu pemeraman campuran yaitu 0 hari, 6 hari, 12 hari dan 18 hari. Hasil penelitian menunjukan lama pemeraman dan persentase penambahan bio-aditif (gondorukem) berpengaruh terhadap karakteristik Marshall campuran aspal beton. Karakteristik terbaik didapat dengan lama pemeraman 12 hari dan penambahan bio-aditif (gondorukem) sebesar $2 \%$.
\end{abstract}

Kata kunci: Asbuton, kinerjacampuran, waktupemeraman, bio-aditif (gondorukem), karakteristikMarshall.
[1]. Disamping itu campuran aspal dengan Asbuton mempunyai kualitas yang lebih rendah dari pada campuran dengan aspal minyak. Kandungan aspal yang tidak homogen pada mineral Asbuton dan besifat keras, sehingga perlu diremajakan. Peremajaan ini berfungsi untuk membuat aspal menjadi lunak sehingga mempunyai kemampuan untuk mengikat agregat, [2]. Kualitas campuran aspal dapat ditingkatkan dengan menggunakan aditif. Penggunaan getah pinus (Gondorukem) sebagai bahan bio-aspal dalam campuran aspal menghasilkan kualitas campuran yang baik dan memenuhi standar berlaku sebagai campuran untuk perkerasan jalan. Nilai stabilitas Marshall mencapai 209,6 kg, menunjukkan kemampuan untuk menerima beban lalu lintas 
yang tinggi [3]. Aplikasi aditif Wetfix-Be pada campuran aspal menggunakan Asbuton, memberikan hasil terbaik pada campuran dengan komposisi Asbuton $25 \%$, aditif $0,3 \%$, dan bahan peremaja 4,5\% dengan nilai stabilitas sebesar $871 \mathrm{~kg}$, Marshall quotient sebesar 272,3 kg/mm, flow sebesar 3,2 mm, VMA sebesar 20,14\%, VIM sebesar 5,67\%, VFA sebesar $71,84 \%$ [4]. Adapun aplikasi aditif gondorukem pada campuran aspahlt concrete binder course (AC-BC), penetrasi 60/70 dengan pengaruh bahan tambah gondorukem terhadap berbagai variasi $1 \%, 2 \%, 3 \%$ dan $5 \%$, memberikan hasil titik lembeknya meningkat sedangkan penetrasinya mengalami penurunan [5]. Aplikasi bahan peremaja yaitu flux butas buatan, yang terdiri dari solar + oli bekas SAE W 20-50 dengan campuran aspal menggunakan Asbuton dan Sifat Marshall campuran HRA dapat disimpulkan bahwa nilai VFWA sebesar $81,759 \%$, VITM sebesar $5,545 \%$, stabilitas sebesar $176,415 \mathrm{~kg}$, Flow sebesar 3,556 $\mathrm{mm}$, Marshall quotient sebesar 49,611 kg/mm diperoleh pada lama pemeraman hari ke 12 [6].

Peningkatan kinerja campuran aspal dengan Asbuton perlu ditingkatkan, sebagai upaya menarik pelaku konstruksi jalan dalam menggunakan Asbuton. Salah satu cara adalah melakukan penelitian dengan menggunakan bahan tambah atau perlakuan terhadap campuran misalnya pemeraman. Penelitian difokuskan untuk mengatasi kekurangan Asbuton, terutama dalam hal pengaktifan aspal dalam mineral Asbuton dan peningkatan kualitasnya. Dalam hal pengaktifan aspal, perlu dilakukan riset tentang lama waktu optimum pemeraman. Sedangkan dalam rangka meningkatkan kualitas, perlu dilakukan inovasi dengan menggunakan aditif.

Diperlukan solusi untuk mendapatkan bahan tambah (aditif) yang murah, mudah didapatkan dan ramah lingkungan. Penggunaan bio-aditif, seperti gondorukem, merupakan inovasi baru untuk mengurangi penggunaan bahan kimia hasil pabrikan. Sehingga secara tidak langsung dapat ikut serta memanfaatkan sumber daya hutan non kayu yang ramah lingkungan.

\section{Metode}

\section{Bahan penelitian}

Bahan yang digunakan untuk membuat ampuran aspal dalam penelitian ini adalah Asbuton B5/20, bahan peremaja, agregat, dan Gondorukem.

\section{Asbuton 5/20}

Ada dua jenis kandungan didalam Asbuton yaitu aspal (bitumen) dan mineral. Berdasarkan kandungan/kadar aspalnya terdapat beberapa jenis Asbuton. Dalam penelitian ini dipakai Asbuton type B5/20 (Gambar 1).

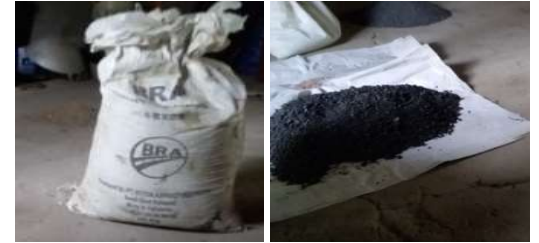

Gambar 1. Asbuton Type B5/20

\section{BahanPeremaja}

Merupakan kombinasi campuran dari aspal, kerosene, dan Bunker Oil (BO) diaduk dalam mesin pencampuran menjadi satu kesatuan (Gambar 2).

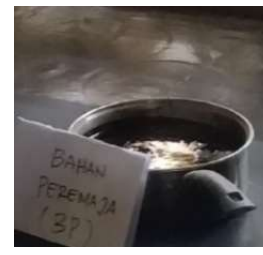

(a)

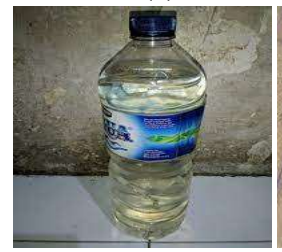

(c)

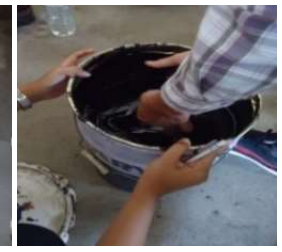

(b)

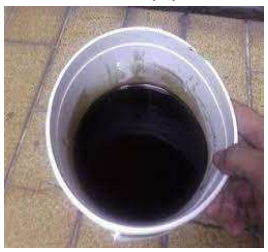

(d)
Gambar 2. (a) Bahan Peremaja dan bahan campurannya: (b) Aspal pen 60/70, (c) Kerosene, (d) Bunker Oil/ BO.

\section{Agregat}

Merupakan agregat pecah dari mesin pemecah batu (stone crusher) yang bersumber dari quarry batu andesit akibat letusan Gunung Rinjani. Agregat pecah tersebut merupakan batuan padat dengan ukuran yang disesuaikan kebutuhan spesifikasi. Terdiri dari agregat kasar (AK), agregat medium (AM), dan agregat halus (AH) dengan ukuran saringan maksimum berturut-turut 3/4", 1/2" dan no. 4" (Gambar 3).

\section{Gondorukem}

Gondorukem merupakan residu yang tertinggal yang diperoleh dari getah pinus, selain itu ada produk tambahan berupa minyak terpentin Gambar 4). [7].

\section{Cara pembuatan benda uji}

Untuk memproduksi campuran aspal dingin, agregat yang telah memenuhi spesifikasi, dicampur sehingga sesuai campuran aspal dingin. Agregat disiapkan dengan cara proporsional yaitu dengan memproporsikan berdasarkan gradasi yang ideal [8]. Penggunaan BP dalam penelitian ini sebesar 4,5\%, proporsi Asbuton ini sebesar 25\% sesuai 
penelitian yang dilakukan terdahulu. Proses pemeraman 0 hari, 6 hari, 12 hari, 18 hari dengan variasi penambahan bioaditif gondorukem yaitu $0 \%, 1 \%, 2 \%$, dan $3 \%$. Pencampuran dilakukan dalam keadaan panas. Agregat dan modifier dipanaskan lalu dicampur dengan Asbuton yang dingin. Setelah material tercampur mencapai suhu ruang $\left(30^{\circ} \mathrm{C}\right)$, dilakukan pemeraman dengan variasi 0 hari, 6 hari, 12 hari, dan 18 hari, pencampuran yang sudah diperam kemudian siap cetakan (mold) untuk campuran yang sudah di peram, tuangkan campuran tersebut dalam cetakan, lalu tusuk pada bagian sisi sebanyak 15 kali dan 10 kali dibagian tengah, setelah itu dipadatkan 2x50 tumbukan Marshall sesuai sifatsifat campuran lataston Bina Marga 2018 (Gambar 5).

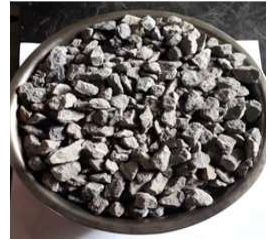

(a)

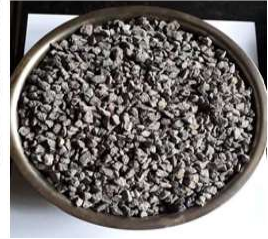

(b)

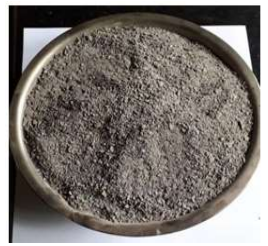

(c)

Gambar 3. (a) Agregat Kasar, (b) Agregat Medium, (c) Agregat Halus

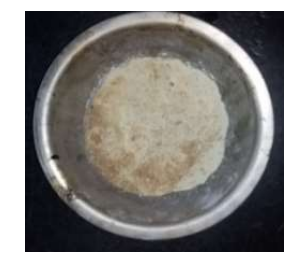

Gambar 4. Gondorukem

Cara pengujian karakteristik volumetrik dan mekanik Pengujian karakteristik volumetrik

Pemeriksaan volumetrik diawali dengan pembersihan kotoran yang menepel pada benda uji tersebut. Termasuk kertas pelapis benda uji yang menempel. Berikan label pada masing-masing benda uji, kemudian mengukur diameter dan tinggi pada benda uji menggunakan jangka sorong (ketelitian $0.1 \mathrm{~mm}$ ). Setelah itu Timbang tiap benda uji kemudian direndam dalam air untuk mendapat berat benda uji dalam air. Setelah mendapatkan berat dalam air, timbang lagi benda uji tersebut untuk mendapat berat kering permukaan jenuh. Proses pengujiannya seperti terlihat pada Gambar 6.

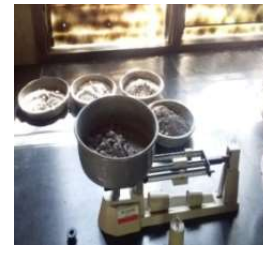

(a)

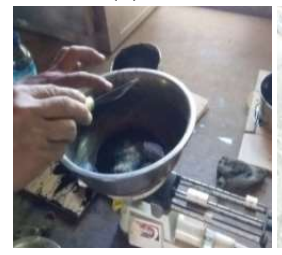

(c)

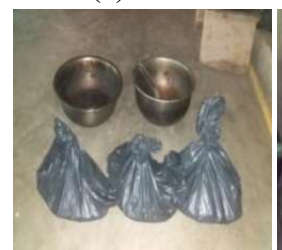

(e)

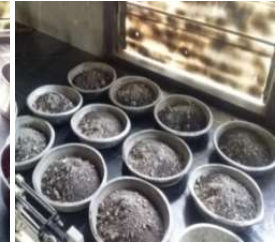

(b)

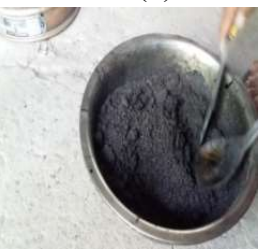

(d)

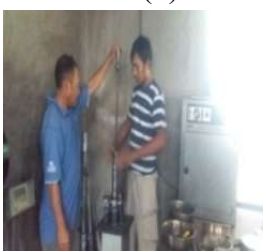

(f)
Gambar 5. Proses Pembuatan Benda uj; (a) Penimbangan material campuran; (b) Material sesuai proporsi; (c) Penimbangan aspal; (d) Campuran aspal; (e) Pemeraman campuran; (g) Pemadatan campuran

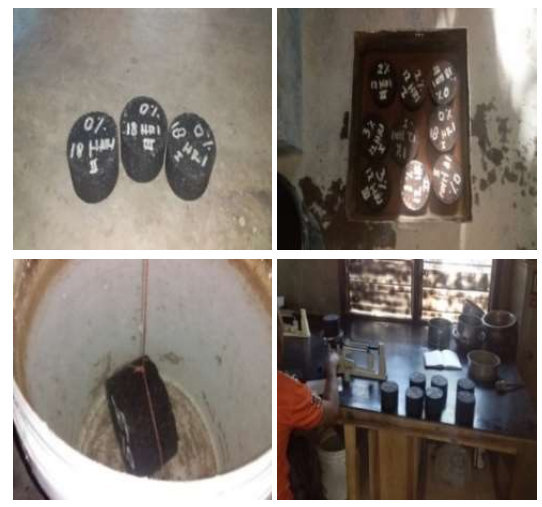

Gambar 6. Proses Pengujian Volumetrik

\section{Pengujian karakteristik mekanik}

Untuk benda uji campuran aspal dingin, masukan benda uji kedalam bak perendam (water bath) minimum 2 jam dengan suhu tetap $(25 \pm 1)^{\circ} \mathrm{C}$, keluarkan benda uji dari bak perendam dan letakkan kedalam segmen bawah kepala penekan dengan catatan bahwa waktu yang diperlukan tidak boleh lebih 30 detik dari saat diangkatnya benda uji dari bak perendaman. Pasang segmen atas dan letakkan keseluruhannya dalam mesin penguji, pasang arloji pengukur pelelehan (flow), sebelum pembebanan, atur jarum arloji tekan pada kedudukan angka nol. Kemudian berikan pembebanan pada 
benda uji sampai pembebanan maksimum, yang ditunjukan oleh jarum arloji tekan. Catat pembebanan maksimum dan kelelehan flow. Gambar 7 menunjukkan proses pengujian campuran aspal.

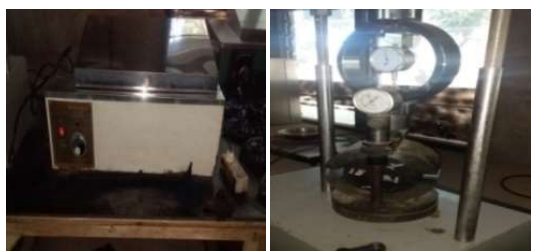

Gambar 7. Proses Pengujian Marshall

Cara analisis dalam perhitungan karakteristik volumetrik dan mekanik

Perhitungan volumetrik

Rongga pori diantara mineral agregat (VMA) dapat dihitung menggunakan rumusan (1)[9].

$V M A=100-\frac{G m b x P s}{G s b}$

dengan:

VMA = Volume pori diantara agregat dalam campuran

Gsb = Berat jenis bulk agregat

$\mathrm{Gmb}=$ Berat jenis bulk campuran padat

Ps = Kandungan agregat, persen terhadap total campuran $(\%)$

Rongga pori dalam campuran beraspal (VIM) dapat dihitung menggunakan rumusan berikut [9].

$V I M=100 x\left(\frac{G m m-G m b}{G m m}\right)$

dengan:

VIM = Volume pori dalam campuran aspal padat

$\mathrm{Gmm}=$ Berat jenis maksimum dari campuran aspal yang belum dipadatkan

$\mathrm{Gmb}=$ Berat jenis bulk campuran padat

Rongga pori yang terisi aspal (VFB) dapat dihitung menggunakan rumusan (3) [9]:

$V F B=100 \times\left(\frac{V M A-V I}{V M A}\right)$

dengan :

VFB = Volume pori yang terisi aspal, persen dari VMA

VMA = Volume pori diantara mineral agregat, persen dari volume bulk campuran

VIM = Rongga di dalam campuran, persen total campuran

\section{Perhitungan mekanik}

Nilai Stabilitas dan Kelelehan (Flow) diperoleh berdasarkan nilai masing-masing benda uji yang ditunjukkan oleh jarum dial. Untuk nilai stabilitas, nilai yang ditunjukkan jarum dial perlu dikonversikan terhadap alat Marshall dengan satuan kilogram. Nilai flow diperoleh seperti halnya cara memperoleh nilai stabilitas berdasarkan nilai masingmasing benda uji yang ditunjukan oleh jarum dial, dalam satuan mm (milimeter). Marshall Quotient Perhitungan nilai MQ dapat dilakukan dengan menggunakan rumusan (4) [10].

$P=\frac{M}{N}$

dengan:

$\mathrm{P}=$ Marshall Quotient $(\mathrm{Kg} / \mathrm{mm})$

$\mathrm{M}=$ Stabilitas $(\mathrm{Kg})$

$\mathrm{N}=$ Flow $(\mathrm{mm})$

\section{Hasil dan Pembahasan}

Hasil pemeriksaan karakteristik material campuran aspal

Pengujian Material Agregat

Hasil pengujian material yaitu pengujian agregat kasar 3/4", agregat medium 3/8", agregat halus dapat di lihat pada Tabel 1.

\section{Hasil PemeriksaanCampuranBeraspal}

Penentuan Bahan Peremaja (BP) Optimum

Sifat Campuran beraspal yang diperiksa untuk mendapatkan BP optimum adalah void in mineral aggregate (VMA), void in mix (VIM), void fill bitumen (VFB), stabilitas, flow dan marshall quotient. Setelah dilakukan evaluasi terhadap persyaratan campuran, maka didapatkan BP optimumnya adalah $4,5 \%$ karena seluruh sifatnya memenuhi syarat seperti terlihat pada Tabel 4.

Sifat Volumetrik Benda Uji

Hasil pengujian sifat volumetrik dengan penambahan bio-aditif(Gondorukem) $0 \%, 1 \%, 2 \%, 3 \%$ dan variasi pemeraman 0 hari, 6 hari, 12 hari, dan 18 hari dapat di lihat pada Tabel 5.

\section{Pengaruh lama pemeraman terhadap sifat volumetrik}

Pencampuran dilakukan dalam keadaan panas baik agregat dan modifier, selesai dipanaskan lalu dicampur dengan Asbuton yang dingin. Setelah masing-masing material tercampur mencapai suhu ruang $\left(30^{\circ} \mathrm{C}\right)$, baru dilakukan pemeraman, kemudian siapkan cetakan (mold) untuk campuran yang sudah di peram.

Voids in the Mineral Aggregat (VMA)

Pada Gambar 8 terlihat bahwa semakin tinggi prosentase bio-aditif dengan lama pemeraman yang sama, nilai VMA semakin kecil. Terjadinya penurunan VMA ketika ditambahkan aditif karena kecilnya jumlah aspal yang mengisi rongga dalam campuran mengalami penurunan. 
Sehingga lapisan kurang mengikat agregat akibatnya perkerasan mudah terjadi stripping [11].

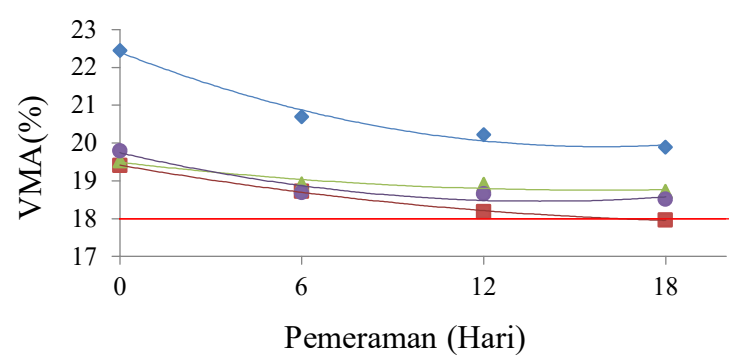

- Aditif (0\%) $-\operatorname{Aditif}(1 \%) \triangle \operatorname{Aditif}(2 \%) \bullet \operatorname{Aditif}(3 \%)$

Gambar 8. Hubungan waktu pemeraman terhadap VMA campuran dengan penambahan aditif $0 \%, 1 \%, 2 \%$, dan $3 \%$

Lama pemeraman juga berpengaruh terhadap nilai VMA. Pada Gambar 8, ditunjukan bahwa semakin lama dilakukan pemeraman, maka VMA semakin kecil. Hal ini disebabkan oleh lama pemeraman, bitumen pada asbuton mengikat butiran agregat semakin menurun sehingga sifat kekedapan, keawetan juga semakin rendah [11]. Dari hasil penelitian ini nilai VMA yang tidak memenuhi adalah pemeraman 18 hari dengan penambahan bio-aditif $1 \%$ sebesar $17,97 \%$, disyaratkan min $18 \%$ [8].

Voids in Mix (VIM)

Pada Gambar 9 terlihat bahwa semakin tinggi prosentase bio-aditif dengan lama pemeraman yang sama, nilai VIM semakin kecil. Terjadinya peningkatan VIM ketika ditambahkan aditif diakibatkan oleh penambahan bio-aditif cenderung menurun, sifat kekedapan udara dan air meningkat, akan tetapi meningkatkan pontensi bleeding karena bahan ikat akan mencair dan naik kepermukaan apabila menerima beban lalu lintas [11].

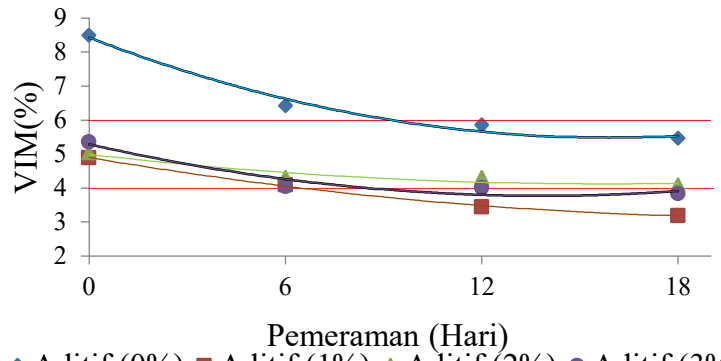

- Aditif $(0 \%)-\operatorname{Aditif}(1 \%) \triangle \operatorname{Aditif}(2 \%) \bullet \operatorname{Aditif}(3 \%)$

Gambar 9. Hubungan waktu pemeraman terhadap VIM campuran dengan penambahan aditif $0 \%, 1 \%, 2 \%$, dan $3 \%$

Lama pemeraman juga berpengaruh terhadap nilai VIM. Pada Gambar 10, ditunjukkan bahwa semakin lama dilakukan pemeraman, maka VIM semakin kecil. Hal ini disebabkan oleh semakin sedikitnya bitumen yang aktif dalam mengisi rongga antar agregat, tingkatan kekakuan tinggi, saat menerima beban lalu lintas akan mudah retak-retak (cracking) [6]. Dari hasil penelitian ini pemeraman 0-6 hari dengan bio-aditif $0 \%$ berturut-turut sebesar 8,5\%, 6,4\%, pemeraman 18 hari dengan bio-aditif $1 \%$ dan 3\% sebesar $3,2 \%, 3,8 \%$, disyaratkan $4 \%-6 \%$, [8].

\section{Voids Fill With Bitumen (VFB)}

Pada Gambar 10 terlihat bahwa semakin tinggi prosentase bio-aditif dengan lama pemeraman yang sama, nilai VFB semakin meningkat. Disebabkan prosentase rongga didalam campuran yang terisi aspal mengalami peningkatan seiring bertambahnya proporsi bio-aditif, nilai VFB meningkat sering terjadi bleeding pada saat temperatur tinggi [11].

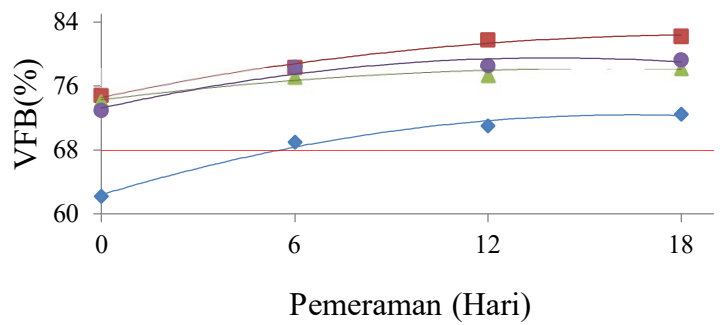

- Aditif $(0 \%)-\operatorname{Aditif}(1 \%) \triangle \operatorname{Aditif}(2 \%) \bullet \operatorname{Aditif}(3 \%)$

Gambar 10. Hubungan waktu pemeraman terhadap VFB campuran dengan penambahan aditif $0 \%, 1 \%, 2 \%$, dan $3 \%$

Lama pemeraman juga berpengaruh terhadap nilai VFB. Pada Gambar 10, ditunjukkan bahwa semakin lama dilakukan pemeraman, maka VFB semakin meningkat. Disebabkan nilai VFB yang besar menunjukkan agregat terselimuti aspal, lebih kedap air dan tidak mudah teroksidasi yang pada akhirnya akan meningkatkaan durabilitas campuran dan jumlah aspal yang mengisi rongga semakin banyak sehingga kekedapan pada campuran akan meningkat. Nilai VFB yang terlalu besar akan mengakibatkan terjadinya bleeding pada saat temperatur tinggi, yang disebabkan VIM yang terlalu kecil [11]. Dari hasil penelitian ini yang tidak memenuhi pemeraman 0 hari pada penambahan bio-aditif $0 \%$ sebesar $62 \%$, disyaratkan $\min 68 \%$ [8].

\section{Sifat Mekanis Benda Uji}

Hasil pengujian sifat mekanik dengan penambahan bioaditif $0 \%, 1 \%, 2 \%, 3 \%$ dan variasi pemeraman 0 hari, 6 hari, 12 hari,dan 18 hari dapat dilihat pada Tabel 6.

\section{Pengaruh lama pemeraman terhadap sifat mekanik Stabilitas(kekuatan)}

Pada Gambar 11 terlihat bahwa semakin tinggi prosentase bio-aditif dengan lama pemeraman yang sama, nilai stabilitas semakin besar. Terjadinya peningkatan stabilitas karena dapat mengisi rongga-rongga dalam campuran menyebabkan interlocking semakin baik, viskositas aspal 
tinggi menjadi lebih kaku dan rapat sehingga tidak bergelombang, alur (rutting) maupun mengalami bleeding [6].

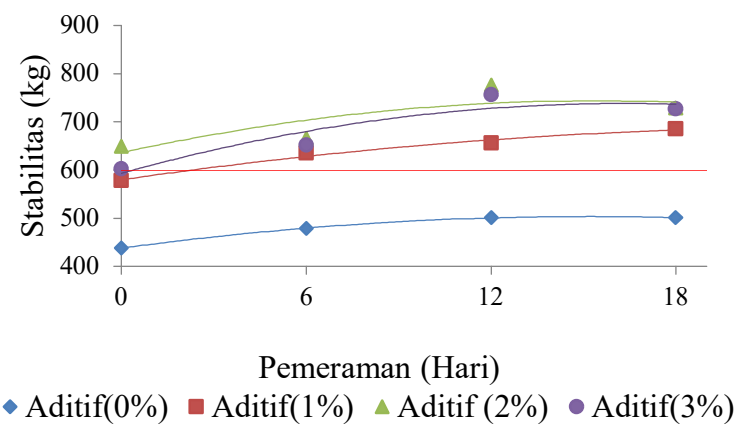

Gambar 11. Hubungan waktu pemeraman terhadap stabilitas campuran dengan penambahan aditif $0 \%, 1 \%, 2 \%$, dan $3 \%$

Lama pemeraman juga berpengaruh terhadap nilai stabilitas. Pada Gambar 11, ditunjukkan bahwa semakin lama dilakukan pemeraman, maka stabilitas meningkat. Hal ini disebabkan oleh bitumen pada Asbuton aktif dengan baik dalam mengikat agregat menyebabkan interlocking sehingga mampu menahan beban lalu lintas [6]. Dari hasil penelitian ini nilai stabilias yang tertinggi pada pemeraman 12 hari dengan bio-aditif $2 \%$ sebesar $776,25 \mathrm{~kg}$, disyaratkan min $600 \mathrm{~kg}$ [8].

Flow (Kelelehan)

Pada Gambar 12 terlihat bahwa semakin tinggi prosentase bio-aditif dengan lama pemeraman yang sama, nilai flow mengalami penurunan kemudian naik lagi nilai flow. Nilai flow rendah disebabkan semakin tinggi nilai penyerapan sehingga aspal yang menyelimuti agregat menjadi tipis sebaliknya nilai flow tinggi disebabkan campuran menjadi semakin plastis sehingga besarnya deformasi pada saat menerima beban meningkat [6].

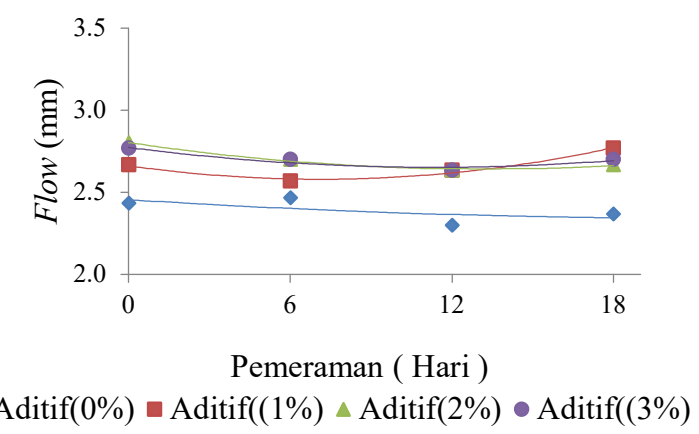

Gambar 12. Hubungan waktu pemeraman terhadap flow campuran dengan penambahan aditif $0 \%, 1 \%, 2 \%$, dan $3 \%$.
Lama pemeraman juga berpengaruh terhadap nilai flow. Pada Gambar 12, ditunjukkan bahwa semakin lama dilakukan pemeraman, maka flow mengalami penurunan kemudian naik lagi nilai flow. Hal ini disebabkan oleh nilai flow mengalami penurunan dari $0 \%$ sampai $2 \%$, disebabkan dalam campuran meningkat kerapatannya sedangkan fleksibilitas menurunan sehingga cenderung bersifat getas. Nilai flow yang naik dari $2 \%$ sampai $3 \%$ menyebabkan nilai flow bersifat plastis, bitumen pada asbuton mulai mengikat agregat sehingga terselimuti [6].

\section{Marshall Quotient (MQ)}

Pada Gambar 13 terlihat bahwa semakin tinggi prosentase aditif dengan lama pemeraman yang sama, nilai marshall quotient semakin meningkat. Terjadinya peningkatan marshall quotient diakibatkan oleh bertambahnya bio-aditif gondorukem sehingga kohesi antar agregat meningkat, campuran menjadi kaku, sebaliknya marshall quotient rendah menunjukkan perkerasan mengalami deformasi yang besar bila menerima beban lalu lintas [11].

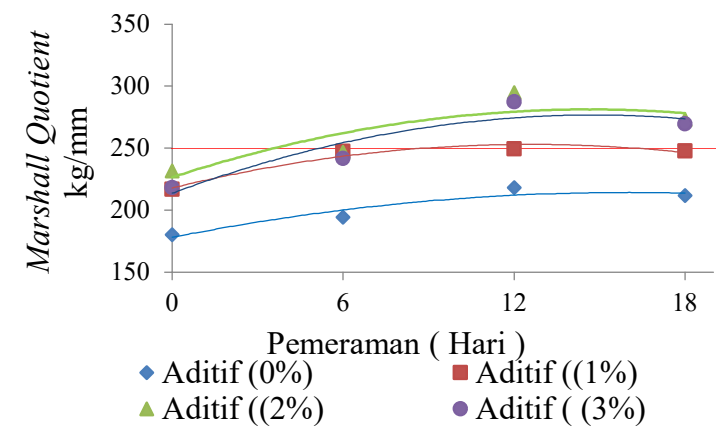

Gambar 13. Hubungan waktu pemeraman terhadap marshall quotient campuran dengan penambahan aditif $0 \%, 1 \%$, $2 \%, 3 \%$

Lama pemeraman juga berpengaruh terhadap nilai marshall quotient. Pada Gambar 13, ditunjukkan bahwa semakin lama dilakukan pemeraman, maka marshall quotient meningkat. Hal ini disebabkan oleh nilai MQ meningkat mengindikasikan kemampuan campuran bitumen di asbuton dalam merespon cepat saat diberikan beban lalu lintas [6]. Dari hasil penelitian ini nilai MQ yang tertinggi pada pemeraman 12 hari dengan bio-aditif $2 \%$ sebesar $274,98 \mathrm{~kg} / \mathrm{mm}$, disyaratkan $\min 250 \mathrm{~kg} / \mathrm{mm}$ [8].

\section{Simpulan}

Dari hasil penelitian ini yaitu mengenai pengaruh lama pemeraman Asbuton dengan menggunakan bio-aditif (Gondorukem) pada prosentase $0 \%, 1 \%, 2 \%, 3 \%$ dan bahan peremaja pada campuran dingin. Dengan sifat volumetrik yaitu nilai VMA yang tidak memenuhi persyaratan pada bioaditif $0 \%$ pada pemeraman 18 hari, nilai VIM tidak 
memenuhi persyaratan pada bio-aditif $0 \%$ pada pemeraman 0 hari, 6 hari sedangkan penambahan bio-aditif $1 \%$ tidak memenuhi persyaratan 12 hari, 18 hari dan penambahan bioaditif 3\% tidak memenuhi persyaratan 18 hari, nilai VFB tidak memenuhi persyaratan pada bio-additif $0 \%$ pada pemeraman 0 hari. Nilai sifat Marshall pada Stabilitas memenuhi persyaratan pada penambahan bio-aditif $2 \%$, lama pemeraman 12 hari, Marshall Quotient yang memenuhi persyaratan pada penambahan bio-additif $2 \%$, lama pemeraman 12 hari. Jadi pengaruh penggunaan Asbuton dengan penambahan bio-aditif dan bahan peremaja sebagai bahan ikat dalam campuran aspal dingin ternyata mempunyai karakteristik Marshall yang terbaik didapat pada pemeraman 12 hari dan $2 \%$ bio-aditif.

\section{Daftar Pustaka}

[1] A. Junaidi, "Pengaruh Variasi Diameter Butiran Asbuton dan Waktu Pemereman Terhadap Karakteristik Campuran Asbuton Agregat secara Dingin,” Tugas Akhir, Jurusan Teknik Sipil UGM, Yokyakarta, 1994.

[2] Simanungkalit P.G.R, "Tinjauan Terhadap Asbuton Salah Satu Bahan dalam Konstruksi Perkerasan Jalan," in Konferensi Tahunan Teknik Jalan Ke1,Departemen Pekerjaan Umum, 1986.

[3] R. Yuniarti, "Modifikasi Aspal Dengan Getah Pinus Dan Fly Ash Untuk Menghasilkan Bio-Aspal," $J$. Sains Teknol. Lingkung., vol. 1, no. 2, 2015.

[4] I. G. Mardawa, "Karakteristik Marshall pada
Campuran Aspal Dingin dengan Asbuton Akibat Dari Penggunaan Aditif Wetfix-BE," Sains Teknol. dan Lingkung., vol. 6, no. 1, pp. 50-60, 2020.

[5] S. Rianung, "Kajian Laboratorium Pengaruh Bahan Tambah Gondorukem pada Asphalt Concrete-Binder Course (AC-BC) Terhadap Nilai Propertis Marshall dan Durabilitas," Tugas Akhir, Universitas Diponegoro, Semarang, Semarang, 2007.

[6] W. T. Kusdiyanto, "Penelitian Pengaruh Lama Pemeraman Asbuton Menggunakan Flux Butas Buatan Sebagai Bahan Peremaja Terhadp HRA dengan Campuran Secara Dingin," Tugas Akhir,JTS FTSP Universitas Islam Indonesia, Yogyakarta, 2000.

[7] I. W. Kuspradini, H., Rosamah, E., Sukaton, E., Arung, E. T, dan Kusuma, Pengenalan Jenis Getah Gum Laktes-Resin. Cetakan pertama, Samarinda: Mulawarman University Press, 2016.

[8] Kementrian Pekerjaan Umum, "Direktorat Jenderal Bina Marga," Spesifikasi Umum, Sep.2018.

[9] S. Sukirman, Beton Aspal Campuran Panas, 3rd ed. Bandung: Institut Teknologi Nasional, 2016.

[10] S. Sukirman, Beton Aspal Campuran Panas, 1 st ed. Jakarta: Granit, 2003.

[11] M. B. Iqbal, "Pengaruh Retona (P 6014 POWDER) Terhadap Karakteristik Campuran Marshall pada KAO," Tugas Akhir,JTS FTSP Universitas Islam Indonesia, Yogyakarta, 2005. 
Tabel 1. Hasil Pengujian Material Agregat

\begin{tabular}{|c|c|c|c|}
\hline Variabelpengujian & Metodepengujian & $\begin{array}{c}\text { Hasil } \\
\text { pemeriksaan }\end{array}$ & Spesifikasi \\
\hline $\begin{array}{l}\text { Keausandenganmesin Los Angeles } \\
\text { Abrassion } \\
\text { GumpalanLempung }\end{array}$ & SNI 2417: 2008 & $19.10 \%$ & maks. $40 \%$ \\
\hline $\begin{array}{l}\text { AK } 3 / 4 " \\
\text { AM } 3 / 8 " \\
\text { Halus }\end{array}$ & SNI $4141: 2005$ & $\begin{array}{l}0.20 \% \\
0.23 \% \\
0.17 \%\end{array}$ & $\begin{array}{l}\text { maks. } 1 \% \\
\text { maks. } 1 \% \\
\text { maks. } 1 \%\end{array}$ \\
\hline Ketahanan (Soundness tes) & & & \\
\hline AM 3/8 " & SNI $3407: 2008$ & $\begin{array}{l}3.86 \% \\
4.29 \%\end{array}$ & $\begin{array}{l}\text { maks. } 10 \\
\% \\
\text { maks. } 10 \\
\%\end{array}$ \\
\hline $\begin{array}{l}\text { Halus } \\
\text { Kelekatanagregatterhadapaspal }\end{array}$ & SNI 2439: 2008 & $\begin{array}{l}4.22 \% \\
98.70 \%\end{array}$ & $\begin{array}{l}\text { maks. } 10 \% \\
\text { min. } 95 \%\end{array}$ \\
\hline Indekkepipihanagregat (\%) & ASTM D4791-10 & $2.80 \%$ & maks. $5 \%$ \\
\hline $\begin{array}{l}\text { BeratJenis (Bulk Specific Grafity).( gr/cc) } \\
\text { AK } 3 / 4 " \\
\text { AM } 3 / 8 " \\
\text { Halus }\end{array}$ & $\begin{array}{l}\text { SNI -03-1969- } \\
1990\end{array}$ & $\begin{array}{l}2.688 \mathrm{gr} / \mathrm{cc} \\
2.675 \mathrm{gr} / \mathrm{cc} \\
2.744 \mathrm{gr} / \mathrm{cc}\end{array}$ & Min.2.5 \\
\hline $\begin{array}{l}\text { BeratJenisKeringPermukaanJenuh (Saturated Surface } \\
\text { Dry).( } \mathrm{gr} / \mathrm{cc}) \\
\text { AK } 3 / 4 " \\
\text { AM } 3 / 8 "\end{array}$ & $\begin{array}{l}\text { SNI-03-1968- } \\
\quad 1990\end{array}$ & $\begin{array}{l}2.732 \mathrm{gr} / \mathrm{cc} \\
2.718 \mathrm{gr} / \mathrm{cc}\end{array}$ & Min.2.5 \\
\hline $\begin{array}{l}\text { Halus } \\
\text { BeratJenisSemu (Apparent Specific Grafity). ( gr/cc) }\end{array}$ & & $2.765 \mathrm{gr} / \mathrm{cc}$ & \\
\hline $\begin{array}{l}\text { AK } 3 / 4 " \\
\text { AM } 3 / 8 " \\
\text { Halus } \\
\text { Penyerapan, }(\%)\end{array}$ & $\begin{array}{l}\text { SNI-03-1968- } \\
1990\end{array}$ & $\begin{array}{l}2.812 \mathrm{gr} / \mathrm{cc} \\
2.795 \mathrm{gr} / \mathrm{cc} \\
2.802 \mathrm{gr} / \mathrm{cc}\end{array}$ & Min.2.5 \\
\hline $\begin{array}{l}\text { AK } 3 / 4 " \\
\text { AM } 3 / 8 "\end{array}$ & & $\begin{array}{l}1.643 \% \\
1.610 \%\end{array}$ & \\
\hline $\begin{array}{l}\text { Halus } \\
\text { Kadar Air Agregat (\%) }\end{array}$ & $\begin{array}{c}\text { SNI -03-1969- } \\
1990\end{array}$ & $0.746 \%$ & Maks. 3\% \\
\hline $\begin{array}{l}\text { AK } 3 / 4 " \\
\text { AM } 3 / 8 " \\
\text { Halus }\end{array}$ & & $\begin{array}{l}1.105 \% \\
1.385 \% \\
1.330 \%\end{array}$ & \\
\hline
\end{tabular}


Tabel 2. Hasil Pengujian Ekstraksi Asbuton

\begin{tabular}{|c|c|c|c|}
\hline \multicolumn{4}{|c|}{ Pengujian Ekstraksi } \\
\hline A & Berattalam dan campuranaspal & & $879.3 \mathrm{Gr}$ \\
\hline $\mathrm{B}$ & Berattalam dan unsur material setelah di ekstraksi & & $739.3 \mathrm{Gr}$ \\
\hline $\mathrm{C}$ & Berattalam & & $173.2 \mathrm{Gr}$ \\
\hline $\mathrm{D}$ & Beratsebelum di ekstraksi & $(\mathrm{A}-\mathrm{C})$ & $706.1 \mathrm{Gr}$ \\
\hline $\mathrm{E}$ & Beratsesudah di ekstraksi & $(\mathrm{B}-\mathrm{C})$ & $566.1 \mathrm{Gr}$ \\
\hline $\mathrm{F}$ & Beratkertas filter dan unsur material & & $16.7 \mathrm{Gr}$ \\
\hline G & Beratkertas filter & & $14.8 \mathrm{Gr}$ \\
\hline $\mathrm{H}$ & Tambahan material pada kertas & $(F-G)$ & $1.9 \mathrm{Gr}$ \\
\hline $\mathrm{I}$ & Beratmangkok dan abu & & $144.2 \mathrm{Gr}$ \\
\hline $\mathrm{J}$ & Beratmangkok & & $140.0 \mathrm{Gr}$ \\
\hline $\mathrm{K}$ & Beratabu pada mangkok & $(\mathrm{I}-\mathrm{J})$ & $4.2 \mathrm{Gr}$ \\
\hline $\mathrm{L}$ & Beratunsur material keseluruhan & $(\mathrm{E}+\mathrm{H}+\mathrm{K})$ & $572.2 \mathrm{Gr}$ \\
\hline M & Berataspaldalamcampuran & $(\mathrm{D}-\mathrm{L})$ & $140.0 \mathrm{Gr}$ \\
\hline $\mathrm{N}$ & $\%$ Aspaldalamcampuran & $100 \mathrm{M} / \mathrm{D}$ & $19.83 \%$ \\
\hline \multicolumn{4}{|c|}{ Tabel 3. Pengujian Aspal Pen $60 / 70$} \\
\hline No & Karakteristik & Persyartan & Hasil \\
\hline 1 & Penetrasi: $2{ }^{\circ} \mathrm{C}: 100 \mathrm{gr} 5$ detik:0,1 mm & $60-79$ & 62.4 \\
\hline 2 & TitikLembek: ${ }^{\top} \mathrm{C}$ & $\geq 48{ }^{\circ} \mathrm{C}$ & 51.5 \\
\hline 3 & Titik Nyala : ${ }^{\mathrm{C}}$ & $\geq 232^{\circ} \mathrm{C}$ & 308 \\
\hline 4 & Daktilitas : $25^{\circ} \mathrm{C}: \mathrm{mm}$ & $\geq 100{ }^{\circ} \mathrm{C}$ & $140 \mathrm{~cm}$ \\
\hline 5 & BeratJenis & $\geq 1.0{ }^{\circ} \mathrm{C}$ & 1.040 \\
\hline 6 & KehilanganBerat (\%), ( $163{ }^{\circ} \mathrm{C}, 5$ jam $)$ & $\leq 0.8^{\circ} \mathrm{C}$ & $0.048 \%$ \\
\hline 7 & Penetrasisetelahkehilnganberat : $25{ }^{\circ} \mathrm{C}: 100 \mathrm{gr} 5$ detik:0,1 mm & $\geq 54^{\circ} \mathrm{C}$ & 55.2 \\
\hline 8 & Daktilitassetelahkehilnganberat $: 25^{\circ} \mathrm{C}: \mathrm{mm}$ & $\geq 100$ & 130 \\
\hline
\end{tabular}

Tabel 4. Hasil Penentuan untuk mendapatkan kadar BP optimum.

\begin{tabular}{lcccccc}
\hline BahanPeremaja (\%) & 3.5 & 4.0 & 4.5 & 5.0 & 5.5 & Spesifikasi \\
\hline Unit Welght (gr/cm3) & 2.234 & 2.246 & 2.263 & 2.254 & 2.241 & $\min 2.00$ \\
Stability ( kg ) & 746.1 & 775.7 & 871 & 811.8 & 759.2 & $\min 600$ \\
Flow ( mm ) & 3.37 & 3.33 & 3.2 & 3.23 & 3.4 & $\min 3.00$ \\
M Q kg / mm & 221.6 & 232.9 & 272.3 & 251.1 & 223.5 & $\min 250$ \\
VIM ( \% ) & 7.85 & 6.87 & 5.67 & 5.56 & 4.19 & $4.0-6.0$ \\
VM A (\%) & 20.65 & 20.48 & 20.14 & 20.71 & 20.92 & $\min 18$ \\
VFA (\%) & 61.96 & 66.46 & 71.84 & 73.18 & 79.96 & $\min 68$ \\
\hline
\end{tabular}

Tabel 5.Hasil Pemeriksaan Sifat VolumetrikCampuranAspal

\begin{tabular}{cccccc}
\hline \multirow{2}{*}{ Sifat Marshall } & Kadar aditif (\%) & 0 Hari & L Hari & 12 Hari & 18 Hari \\
\hline \multirow{2}{*}{ VMA } & $0 \%$ & 22 & 21 & 20 & 20 \\
min 18 & $1 \%$ & 19.40 & 18.72 & 18.19 & 17.97 \\
& $2 \%$ & 19.53 & 18.92 & 18.92 & 18.73 \\
& $3 \%$ & 19.80 & 18.69 & 18.66 & 18.52 \\
\hline VIM & $0 \%$ & 8.5 & 6.4 & 5.9 & 5.5 \\
$4.0-6.0$ & $1 \%$ & 4.9 & 4.1 & 3.5 & 3.2 \\
& $2 \%$ & 5.0 & 4.3 & 4.3 & 4.1 \\
VFB & $3 \%$ & 5.4 & 4.1 & 4.0 & 3.8 \\
min 68 & $0 \%$ & 62 & 69 & 71 & 73 \\
& $1 \%$ & 74.86 & 78.34 & 81.80 & 82.24 \\
& $2 \%$ & 74.20 & 77.20 & 77.37 & 78.20 \\
\hline
\end{tabular}


Tabel 6. Hasil Pemeriksaan sifat Mekanis Uji Marshall

\begin{tabular}{cccccc}
\hline \multirow{2}{*}{ Sifat Marshall } & Kadar aditif & \multicolumn{4}{c}{ LamaPermeraman } \\
\cline { 3 - 6 } & $(\%)$ & 0 Hari & 6 Hari & 12 Hari & 18 Hari \\
\hline \multirow{2}{*}{ Stabilitas $(\mathrm{kg})$} & $0 \%$ & 438 & 479 & 501 & 501 \\
min. 600 & $1 \%$ & 577.72 & 634.80 & 656.01 & 685.33 \\
& $2 \%$ & 648.70 & 666.04 & 776.25 & 728.25 \\
& $3 \%$ & 602.86 & 652.23 & 756.14 & 727.27 \\
Flow $(\mathrm{mm})$ & $0 \%$ & 2.4 & 2.5 & 2.3 & 2.4 \\
- & $1 \%$ & 2.7 & 2.6 & 2.6 & 2.8 \\
& $2 \%$ & 2.8 & 2.7 & 2.6 & 2.7 \\
Marshall Quotient & $3 \%$ & 2.8 & 2.7 & 2.6 & 2.7 \\
(Kg/mm) & $0 \%$ & 180 & 194 & 218 & 212 \\
min. 250 & $1 \%$ & 216.65 & 247.33 & 249.12 & 247.71 \\
& $2 \%$ & 231.68 & 246.68 & 294.78 & 273.09 \\
& $3 \%$ & 217.90 & 241.57 & 287.14 & 269.36 \\
\hline
\end{tabular}

